\title{
DNA damage and postural balance in multiple sclerosis patients
}

\author{
Dano ao DNA e equilíbrio postural de portadores de Esclerose Múltipla
}

\begin{abstract}
Karla Mendonça Menezes ${ }^{[a]}$, Thaís Doeler Algarve ${ }^{[a]}$, Fábio Saraiva Flôres ${ }^{[a, b]}$, Ivana Beatrice Mânica Cruz ${ }^{[a]}$, Fernando Copetti ${ }^{[a]}$, Aron Ferreira Silveira ${ }^{[a]^{*}}$
\end{abstract}

[a] Universidade Federal de Santa Maria (UFSM), Santa Maria, RS, Brazil

[b] Universidade de Lisboa (ULISBOA), Lisbon, Portugal

\section{Abstract}

Introduction: Multiple Sclerosis (MS) is a chronic inflammatory disease characterized by infiltration of inflammatory cells on the Central Nervous System (CNS). There is evidence that cumulative DNA damage can contribute to various mechanisms underlying MS lesions. Changes in postural balance are frequent observations in subjects with MS. Objective: Evaluated the DNA damage index (DDI)) and postural balance in patients with MS. Methods: A case-control study was conducted with 28 subjects matched for sex, age, and body mass index, divided into MS group and control. The DDI was assessed by comet assay and postural balance through recording the body oscillations of the center of pressure (COP), in the anterior-posterior and lateral middle directions. Results: Showed higher DDI in MS patients $(21.3 \pm 4.8)$ than controls $(7.9 \pm 6.1)$. Significant differences between groups were also noted in postural control parameters. The wider ranges of postural sway were observed in the MS group. The associations between DDI and postural control parameters showed weak, but significant correlations. No associations were found between DDI and time of diagnosis of MS. Conclusion: People with MS had higher DDI and larger body oscillations than healthy individuals.

Keywords: DNA Damage. Multiple Sclerosis. Comet Assay. Postural Balance.

\footnotetext{
* KMM: Doctoral student, e-mail: karlam.ef@gmail.com TDA: Doctoral student, e-mail:thais.algarve@gmail.com FSF: Doctoral student, e-mail: flores.saraiva@gmail.com IBMC: PhD, e-mail: ibmcruz@hotmail.com FC: PhD, e-mail: copettif@gmail.com AFS: PhD, e-mail: aronfer@gmail.com
} 


\section{Resumo}

Introdução: A Esclerose Múltipla (EM) é uma doença inflamatório crônica caracterizada pela infiltração de células inflamatórias no Sistema Nervoso Central (SNC). Há evidencias de que danos cumulativos ao DNA possam contribuir para vários mecanismos subjacentes às lesões da EM. As alterações no equilíbrio postural são observações frequentes nos sujeitos com EM. Objetivo: Este estudo avaliou os índices de dano ao DNA (ID) e equilíbrio postural em portadores de Esclerose Múltipla (EM). Métodos: Um estudo de caso-controle foi conduzido com 28 sujeitos pareados por sexo, idade e índice de massa corporal, divididos em grupo EM e controle. $O$ ID foi avaliado pelo ensaio cometa e o equilibro postural através do registro das oscilações corporais relativas ao deslocamento centro de pressão (COP) nas direções antero posterior e médio lateral. Resultados: Maiores ID em portadores de EM $(21,3 \pm 4,8)$ do que controles $(7,9 \pm 6,1)$. Diferenças significativas entre os grupos também foram percebidas nos parâmetros do controle postural. As maiores amplitudes de oscilação foram observadas no grupo EM para ambas as direções. As associações entre o ID e parâmetros do controle postural apresentaram correlações fracas e significativas. Não foram encontradas associações entre ID e tempo de diagnóstico de EM. Conclusão: Portadores de EM apresentaram maior ID e maiores oscilações corporais do que controles saudáveis.

Palavras-chave: Dano ao DNA. Esclerose Múltipla. Ensaio Cometa. Equilíbrio Postural.

\section{Introduction}

Genetic and environmental factors may contribute significantly to the development of several comorbidities. Current studies suggest that accumulation of damage to genetic material, DNA (deoxyribonucleic acid), induced by the increase of Reactive Oxygen Species (ROS), results in decreased of the physiological performance of the affected cells $(1-3)$.

The imbalance produced in the body by excessive generation of free radicals (or rate of removal of these species) is known as oxidative stress. It may be induced by several physical and chemical agents in the environment, as well as compounds produced by cell metabolism $(1,2)$. When ROS overproduce cellular antioxidant capacity, the resulting oxidative stress may generate damage to macromolecules such as lipids, proteins, and nucleotides $(2,4-6)$. Recent research suggests that the incidence of oxidative stress may be associated with premature aging and cardiovascular and neurodegenerative diseases (5 - 8). Accordingly, ROS may contribute to various mechanisms underlying Multiple Sclerosis (MS) lesions $(6,7)$.

MS is a chronic neuropathology characterized by infiltration of inflammatory cells into the central nervous system (CNS) (9 - 11). Epidemiological studies suggest that MS appears in early adulthood and is currently the most common cause of physical disability (12). In Brazil, the distribution and clinical characteristics of MS have not been established. However, recent studies suggest rates of 15 cases $/ 100,000$ in habitants in the south and southeast regions $(13-16)$.

The factors that influence the appearance of this pathology have not been fully clarified. Nevertheless, the most accepted pathogenic hypothesis is that MS is mediated by genetic predisposition, associated with an unknown environmental factor. When they meet, a dysfunction is triggered in the immune system. The predominant pathological characteristic in MS is the presence of focal demyelinating lesions, including axonal damage and loss of oligodendrocytes $(4,6,7,9)$.

The MS is usually heterogeneous and tends to evolve through relapsing-remitting episodes, resulting in distinct clinical forms, depending on the location of the lesions (9). The progressive character, the variability of location, the volume of lesions and the sequence of appearance, can trigger numerous clinical signs and symptoms that compromise functional activities (17) and postural control mechanisms in MS patients (18 - 20).

Postural control is the result of complex interactions between the musculoskeletal and neuromuscular systems, including sensory components such as vision, proprioceptive and vestibular system (21). In 
MS patients, the measurement of center of pressure (COP) displacement, showed changes in postural control of newly diagnosed individuals that had not reported postural instability (22).

Considering the evidence that ROS may contribute to various mechanisms underlying MS lesions and frequent observations of impaired postural control in these subjects, this study aimed to evaluate the DNA damage index (DDI) and postural control in MS patients compared with healthy controls. Moreover, check whether there is a relationship between DDI and postural control parameters.

\section{Methods}

This case-control study was carried out with MS patients, members of an association of MS patients. An anamnesis was performed to characterize the subjects and possible bias factors of the study (clinical history, use of physical or chemical therapy and smoking). Fourteen MS patients were included in the study. After the MS group had been formed, 14 healthy subjects were selected. They were matched for age, gender and body mass index (BMI) with the group of MS subjects. Members of the control group were recruited by announcements in newspapers and social media. A total of 28 subjects (20 male and 8 female, ranging 20 to 60 years, $M=24.15$ $\mathrm{SD}=2.14$ ) participated in the study. All subjects were volunteers. None had history of smoking or associated diseases. Everyone was able to remain standing, for at least one minute, without the use of assistive devices. The procedures were approved in its ethical and methodological aspects in Opinion No. 23081.009954 / 2009-77. All subjects signed an informed consent form.

DNA damage was detected by the alkaline version of the comet assay, performed as described by Singh et al. (23) in accordance with the general guidelines (24 - 26). The collection of the comet assay was performed using $5 \mathrm{ml}$ of peripheral blood, by venipuncture, using disposable plastic syringes.

The samples were transferred into tubes with EDTA (ethylenediaminetetraacetic acid) anticoagulant, stored in the dark and protected from heat. Time between collection and processing of the samples did not exceed four hours. All samples were processed in triplicate. Were randomly selected 100 cell images, of each blade. The images were analyzed by two double-blind evaluators, using a binocular optical microscope (400x magnification).

The visual classification of morphological aspects of cells into five categories ( 0 - 4), as suggested by Collins et al. (25), was based on the migration of nuclear DNA fragments. Category 0 included cells with spherical nucleus and no apparent tail (undamaged cells), while small-headed, long-tailed and diffuse cells were included in category 4 . The remaining cells were classified according to intermediate features. Thus, given the number of cells in each category, DNA damage index (DDI) was calculated in arbitrary units (au), considering the sum of all cells counted (100) and classified into categories $0,1,2,3$ and 4 . Thus, DDI can vary from zero (no damage) to 400 (all cells at maximum damage).

Postural control was evaluated by stabilometry, using records of center of pressure (COP) displacement of the subjects in quiet standing posture, standing on an OR6-7 AMTI force platform (Advanced Mechanical Technologies, Inc.), at a sampling frequency of 100 Hz. During data collection, the subjects remained barefoot in bipedal quiet standing position with feet hip-width apart. A fixed target was arranged at eye level and one meter away for visual reference. Each subject performed three 30-second trials.

The data collected in the system were processed through the Software Matlab 7.3 (Matrix Laboratory Mathworks Inc., EUA). The following COP parameters were considered for analysis of postural control: 1) amplitude of anteroposterior displacement (COPap) - distance between maximum and minimum COP displacement in the anteroposterior direction and 2) amplitude of medial-lateral displacement (COPml) - distance between maximum and minimum COP displacement in the medial-lateral direction.

Statistical analyses were conducted using software SPSS, version 17.0. The Kolmogorof-Smirnoff test ruled out the hypothesis of normal distribution of data. The comparison of groups was performed using the Mann-Whitney test. An additional analysis was conducted only for the MS group, using the Spearman test for correlation between COPap and COPml values and age, time since diagnosis and DDI. In all comparisons, the confidence level was set at 95\%.

\section{Results}

The characteristics of subjects with MS and healthy controls are shown in Table 1. 
Table 1 - Profile of subjects

\begin{tabular}{lccc}
\hline & MS & Control & p-value \\
\hline Age (years) & & & \\
Mean & 41.14 & 39.80 & 0.40 \\
DP & 0.1 & 5.14 & \\
Gender & & & \\
$\quad$ Male & 10 & 10 & 1.00 \\
$\quad$ Female & 4 & 4 & \\
Body Mass Index $\left(\mathbf{k g} / \mathrm{m}^{2}\right)$ & & & \\
$\quad$ Mean & 24.05 & 23.8 & 0.58 \\
DP & 2.42 & 1.87 & \\
\hline
\end{tabular}

All subjects in the MS group were experiencing clinical remission of the disease (absence of outbreaks for at least 30 days prior to data collection), were receiving immunosuppressive therapy and participated in weekly physiotherapy sessions. Time since diagnosis of MS was $7.28 \pm 7.41$ years (minimum of three and maximum of 24 years). The number of outbreaks occurring since diagnosis was not available.

Figure 1 shows the results of the comparative analysis between the groups for DNA damage index (DDI).

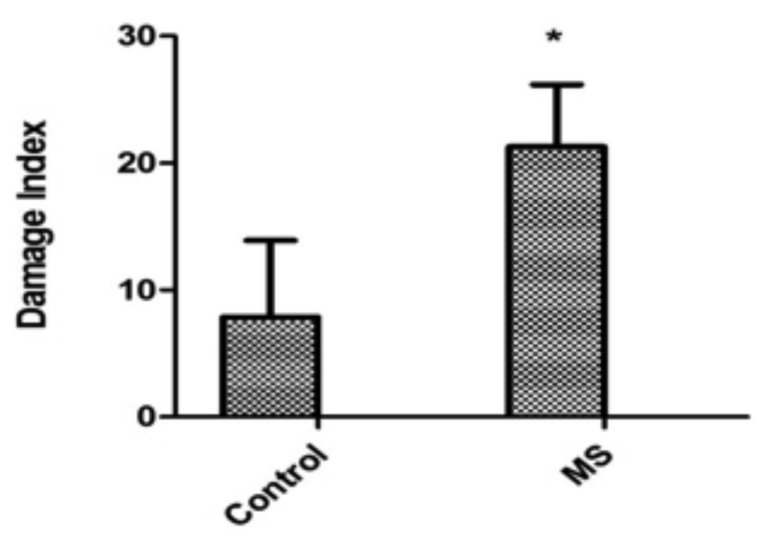

Figure 1- DNA damage index in control and MS group. Note: ${ }^{\star} p<0.05$ Mann-Whitney Test.

The analysis of DDI indicated significant differences between groups ( $p=0.0001)$. The control group had a DDI of $7.9 \pm 6.1$ while the MS group showed a DDI of $21.3 \pm 4.8$.

Figure 2 shows the evaluation of subjects' postural control in quiet standing posture.

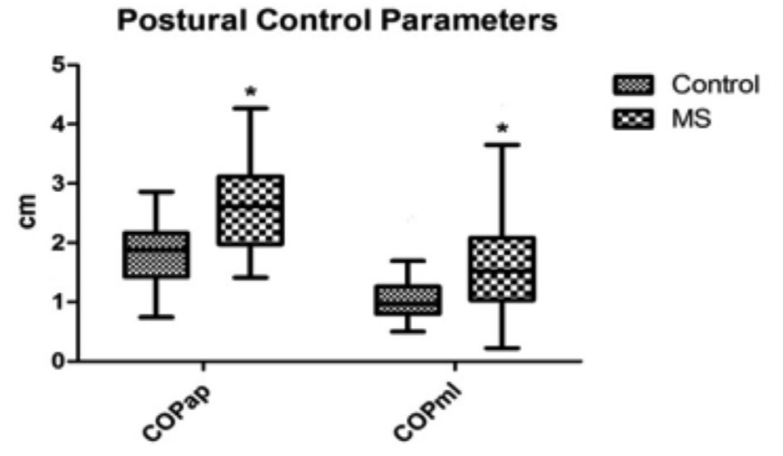

Figure 2 - COP displacement in the control and multiple sclerosis groups.

Note: ${ }^{\star} p<0.05$ Mann-Whitney Test.

The MS group had larger sway amplitudes in both planes of motion, with average values of $2.65 \pm 0.71$ $\mathrm{cm}$ for COP while the healthy controls had a mean of $1.83 \pm 0.45 \mathrm{~cm}(\mathrm{p}=0.03)$. For COPml, there was an average of $1.75 \pm 1.01 \mathrm{~cm}$ for the MS group and 1.07 $\pm 0.41 \mathrm{~cm}$ for the healthy controls $(\mathrm{p}=0.001)$.

An analysis with the MS group only correlated COP amplitudes with age, time since diagnosis of MS and DDI. The results of these comparisons showed weak, but significant correlations between DDI and COPap ( $\mathrm{r}=0.33 \mathrm{p}=0.02)$ and DDI and COPml ( $\mathrm{r}=0.31$ $p=0.04)$. The other associations considered did not show significant correlations.

\section{Discussion}

This study aimed to evaluate the DDI and postural control parameters of MS patients compared with healthy control and observe whether, in MS patients, adjacent variables such as age, gender, duration of disease progression and control postural parameters are associated with DNA damage index.

The results indicated that MS patients have higher DDI than healthy controls. When considering only the MS group, weak but significant correlations were found between DDI and postural control parameters.

DNA damage can be induced by several physical and chemical agents in the environment, as well as by compounds produced by cellular metabolism $(2,3)$. There is evidence that DNA damage resulting from excessive accumulation of ROS, often referred to as free radicals, contribute to various clinical conditions $(3,26)$. Although it is not yet clear 
how oxidative stress influences the etiology of neurodegenerative diseases, some studies suggest that increased ROS production is involved in the pathogenesis of diseases such as Parkinson's and Alzheimer's (5, 27 - 29).

Little is known about the types of cells affected by ROS, in MS patients. However, compared with healthy controls, studies have shown increased activity of ROS and/or deficiencies in important antioxidant enzymes (8). Some studies have shown that ROS may contribute to various mechanisms underlying MS lesions $(4,6,7)$. These tests suggest that ROS produced in monocyte-endothelial interactions, trigger changes in the cytoskeleton, and cause loss of blood-brain barrier integrity and subsequent extravasation of leukocytes into the CNS (6). In addition, infiltrating leukocytes can produce large amounts of ROS that induce myelin phagocytosis and macrophage breakdown $(4,7)$, oligodendroglial damage (6) and neuronal and axonal injury (7). Together, these implications trigger a series of characteristic neurological symptoms and signs of MS that compromise functional activities of subjects affected by this pathogenesis.

Changes in postural control mechanisms are frequent manifestations of dysfunctions observed in MS patients $(17-20,22)$. When compared to the control group, subjects with MS showed higher body sways in both planes of motion. A similar observation was described in a study (19) evaluating postural control of women with MS in different evaluation conditions, including the quasi-static standing position. The authors observed higher body sways for people with MS compared with healthy controls.

The association between postural balance and oxidative metabolism indicators was investigated in a study with seven subjects that had the MachadoJoseph disease (30). The study evaluated DNA damage using the comet assay and the postural balance by dynamic posturography through six sensory organization tests. Moderate and significant correlations were observed between DNA damage index and two of the tests investigated. The results showed that worsened performance of the organization of sensory tests were associated with increased DNA damage.

Postural control is the result of complex interactions between the musculoskeletal and neuromuscular systems, including sensory components such as vision and the proprioceptive and vestibular systems (21), and the extent of cells that can be affected by ROS is not known yet $(8,29)$. For this reason, this study attempted to establish a relationship between postural control parameters and DNA damage index observed in MS patients. The findings suggest that higher postural sway, in both anteroposterior as medial-lateral directions, may be associated with higher DDI. The correlations observed in this study were significant and weak. A hypothesis is that weak correlations were influenced by sample size (14 MS subjects).

\section{Conclusion}

The study evaluated DNA damage using the comet assay and the postural balance by dynamic posturography through six sensory organization tests. Moderate and significant correlations were observed between DDI and two of the tests investigated. The results showed that worsened performance of the organization of sensory tests were associated with increased DNA damage.

\section{References}

1. Cooke MS, Evans MD, Dizdaroglu M, Lunec J. Oxidative DNA damage: mechanisms, mutation, and disease. Faseb J. 2003;17(10):1195-214.

2. D'Errico M, Parlanti E, Dogliotti E. Mechanism of oxidative DNA damage repair and relevance to human pathology. Mutat Res Rev Mutat Res. 2008;659(1-2):4-14.

3. Evans MD, Dizdaroglu M, Cooke MS. Oxidative DNA damage and disease: induction, repair and significance. Mutat Res Rev Mutat Res. 2004;567(1):1-61.

4. van der Goes A, Brouwer J, Hoekstra K, Roos D, van den Berg TK, Dijkstra CD. Reactive oxygen species are required for the phagocytosis of myelin by macrophages. J Neuroimmunol. 1998;92(1-2):67-75. 
5. Kadioglu E, Sardas S, Aslan S, Isik E, Esat Karakaya A. Detection of oxidative DAN damage in lymphocytes of patients with Alzheimer's disease. Biomarkers. 2004;9(2):203-9.

6. van Horssen JSG, Drexhage J, Hazes T, Dijkstra CD, van der Valk P, Vries HE. Severe oxidative damage in multiple sclerosis lesions coincides with enhanced antioxidant enzyme expression. Free Radic Biol Med. 2008;45(12):1729-37.

7. Gilgun-Sherki Y, Melamed E, Offen D. The role of oxidative stress in the pathogenesis of multiple sclerosis: The need for effective antioxidant therapy. J Neurol. 2004;251(3):261-8.

8. van Horssen J, Witte M, Schreibelt G, Vries H. Radical changes in multiple sclerosis pathogenesis. Biochim Biophys Acta. 2011;1812(2):141-50.

9. Korneck B, Lassmann H. Neuropathology of multiple sclerosis - new concepts. Brain Res Bull. 2003;61(3):321-6.

10. Calebresi P. Diagnosis and management of multiple sclerosis. Am Fam Physician. 2004;70(10):1935-44.

11. Lana-Peixoto MA, Callegaro D, Moreira MA, Campos GB, Marchiori PE, Gabbai AA, et al. The BCTRIMS Expanded Consensus on treatment of multiple sclerosis: III. Evidence and recommendationbased guidelines. Arq Neuropsiquiatr. 2002;60(3):881-6.

12. DeBolt L, McCubbin J. The effects of home-based resistance exercise on balance, power, and mobility in adults with multiple sclerosis. Arch Phys Med Rehabil. 2004;85(2):290-7.

13. Finkelsztejn A, Cristovam RA, Moraes GS, Lopes MG, Silva AV, Garcia MS, et al. Clinical Features of Multiple Sclerosis in the South of Brazil. Arq Neuropsiquiatr. 2009;67(4):1071-5.

14. Papais-Alvarenga R, Santos C, Abreu J, Siqueira H, Camargo S, Almeida A. Esclerose Múltipla (EM): Perfil clínico e evolutivo no município do Rio de Janeiro. Rev bras Neurol. 1995;31(2):75-87.

15. Grzesiuk A. Clinical and epidemiologic characteristics of 20 patients with multiple sclerosis in Cuiabá - Mato Grosso, Brazil. Arq Neuropsiquiatr. 2006;64(3A):635-8.
16. Callegaro D, Goldbaum M, Morais L, Tilbery CP, Moreira MA, Gabbai AA, et al. The prevalence of multiple sclerosis in the city of São Paulo, Brasil, 1997. Acta Neurol Scand. 2001;104(4):208-13.

17. Martin C, Galea M, Phillips B, Kilpatrick T, Butzkueven H. Gait and balance parameters as clinical markers of disease progression in early multiple sclerosis. 18th Meeting of the European Neurological Society; 2008 Jun 07-11.

18. 18. Emmerik RV, Remelius J, Johnson M, Chung L, KentBraun J. Postural control in women with multiple sclerosis: Effects of task, vision and symptomatic fatigue. Gait Posture. 2010;32(4):608-14.

19. Porosiñska A, Pierzcha K, Mentel M, Karpe J. Evaluation of postural balance control in patients with multiple sclerosis - effect of different sensory conditions and arithmetic task execution. A pilot stud. Neurol Neurochir Pol. 2010;44(1):35-42.

20. Sosnoff J, Shin S, Motl R. Multiple Sclerosis and Postural Control: The Role of Spasticity. Arch Phys Med Rehabil. 2010;91(1):93-9.

21. Shumway-Cook A, Woollacott M. Controle Motor: Teoria e Aplicações Práticas. 2nd ed. São Paulo: Manole; 2003.

22. Karst G, Venema D, Roehrs T, Tyler A. Center of Pressure Measures during Standing Tasks in Minimally Impaired Persons with Multiple Sclerosis. J Neurol PhysTher. 2005;29(4):170-80.

23. Singh NP, McCoy MT, Tice RR, Schneider EL. A simple technique for quantitation of low levels of DNA damage in individual cells. Exp Cell Res. 1988;175(1):184-91.

24. Ross G, Mcmillan T, Wilcox P, Collins AR. The single cell microgel electrophoresis assay (comet assay): technical aspects and applications. Mutat Res. 1995;337(1):57-60.

25. Collins AR, Oscoz AA, Brunborg G, Gaivao I, Giovannelli L, Kruszewski M, et al. The comet assay: topical issues. Mutagenesis. 2008;23(3):143-51. 
26. Hartmann A, Agurell E, Beevers C, Brendler-Schwaab $\mathrm{S}$, Burlinson B, Clay $\mathrm{P}$, et al. Recommendations for conducting the in vivo alkaline Comet assay. Mutagenesis. 2003;18(1):45-51.

27. Rao KS. Free Radical Induced Oxidative damage to DNA: Relation to Brain Aging and Neurological Disorders. Indian J Biochem Biophys. 2009;46(1):9-15.

28. Reddy VP, Zhu XW, Perry G, Smith MA. Oxidative Stress in Diabetes and Alzheimer's Disease. J Alzheimers Dis. 2009;16(4):763-74.

29. LeVine SM. The role of reactive oxygen species in the pathogenesis of multiple sclerosis. Med Hypotheses. 1992;39(3):271-4
30. Pacheco L. Avaliação do equilíbrio, desempenho funcional e do metabolismo oxidativo em portadores da doença de Machado-Joseph [master's thesis]. Santa Maria (RS): Universidade Federal de Santa Maria; 2012.97 p.
Received in 04/04/2016

Recebido em 04/04/2016

Approved in 04/10/2017

Aprovado em 10/04/2017 